\title{
Pengembangan Media Pembelajaran Berbasis Macromedia Flash Bermuatan Problem Posing terhadap Kemampuan Pemecahan Masalah Matematis
}

\author{
Hodiyanto $^{1^{*}}$, Yudi Darma ${ }^{3}$, dan Syarif R S Putra ${ }^{3}$ \\ 1,2,3 Program Studi Pendidikan Matematika, IKIP PGRI Pontianak \\ Jalan Ampera No. 8 Pontianak, Indonesia

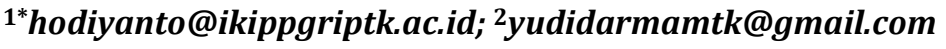

Artikel diterima: 12-12-2019, direvisi: 27-05-2020, diterbitkan: 31-05-2020

\begin{abstract}
Abstrak
Tujuan penelitian ini ingin menghasilkan media pembelajaran macromedia flash bermuatan problem posing terhadap kemampuan pemecahan masalah matematis yang mencapai kriteria valid, kepraktisan, dan keefektifan. Metode penelitian ini adalah penelitian pengembangan dengan model rancangan 4-D oleh Thiagarajan, yaitu Define, Design, Develop, dan Desseminate. Tetapi pada penelitian ini hanya pada tahap pengembangan saja. Subjek dalam penelitian ini adalah siswa kelas VIII SMP Negeri 5 Sukadana sebanyak 20 siswa, ahli dan guru. Instrumen yang digunakan dalam penelitian ini adalah lembar validasi, angket dan soal posttest. Berdasarkan hasil penelitian diperoleh hasil validasi macromedia flash bermuatan problem posing memiliki kriteria sangat valid. Tingkat kepraktisan terhadap macromedia flash bermuatan problem posing memiliki kriteria sangat praktis, tingkat keefektifan terhadap macromedia flash bermuatan problem posing tergolong kriteria sangat efektif. Dengan demikian dapat disimpulkan bahwa macromedia flash bermuatan problem posing yang dikembangkan dapat digunakan karena memenuhi kriteria kevalidan yang sangat valid, kepraktisan yang sangat praktis, dan keefektifan yang efektif.

Kata Kunci: Pengembangan Media Pembelajaran, Macromedia Flash, Kemampuan Pemecahan Masalah Matematis, Problem Posing.

Development of Macromedia Flash-Based Learning Media with Problem Posing to Mathematical Problem Solving Ability

Abstract

The purpose of this study is to produce Macromedia flash learning media containing problem posing to mathematical problem-solving abilities that reach valid criteria, practicality, and effectiveness. This research method is a research development with a 4-D design model by Thiagarajan: Define, Design, Develop, and Disseminate. But this research is only at the development stage. The subjects in this study were 20th-grade students of SMP Negeri 5 Sukadana, experts, and teachers. The instruments used in this study were validation sheets, questionnaires, and posttest questions. Based on the research results obtained by the results of validation Macromedia flash loaded posing problem has very valid criteria. The level of practicality with problem-posing Macromedia flash has very practical criteria, the level of effectiveness with problem-posing Macromedia flash is classified as very effective criteria. Thus it can be concluded that Macromedia flash with posing problem developed can be used.

Keywords: Learning Media Development, Macromedia Flash, Mathematical Problem Solving Ability, Problem Posing.
\end{abstract}




\section{Pendahuluan}

National Council of Teachers of Mathematics (NCTM)

(2000)

mengungkapkan bahwa terdapat lima standar yang semestinya dikuasai oleh peserta didik dalam belajar matematika yaitu: pemecahan masalah, penalaran dan pembuktian, koneksi, komunikasi, dan representasi. Kemampuan pemecahan masalah matematis adalah satu kemampuan yang semestinya harus dikuasai oleh peserta didik dalam belajar matematika (Rinaldi \& Afriansyah, 2019; Latifah \& Luritawaty, 2020; Hanifah \& Nuraeni, 2020).

Ruseffendi menyatakan bahwa sesuatu disebut masalah jika sesuatu itu dianggap baru bagi yang bersangkutan dan tentunya sesuai dengan kondisi dan perkembangannya serta memiliki pengetahuan prasyarat (Hendriana, dkk. 2017).

Berhasil dan tidaknya peserta didik dalam belajar dapat dilihat dari bagaimana dia dapat menyelesaikan permasalahan yang dihadapinya baik itu dalam pembelajaran maupun kegiatan di luar pembelajaran. Berdasarkan hasil wawancara terhadap guru bidang studi matematika kelas VIII SMP Negeri 5 Sukadana diperoleh informasi bahwa kemampuan siswa dalam menyelesaikan soal kemampuan pemecahan masalah matematis masih rendah. Peneliti mencoba memberikan soal kemampuan pemecahan masalah matematis kepada siswa untuk mengecek dan memperkuat hasil wawancara dengan guru yang

bersangkutan. Ternyata hasilnya menunjukkan bahwa kemampuan pemecahan masalah matematis siswa masih rendah dengan rerata di bawah 30 .

Akibatnya, perkembangan kemampuan pemecahan masalah matematis pada siswa menjadi terhambat. Oleh sebab itu, diperlukan suatu media pembelajaran yang dapat membantu berkembangnya kemampuan pemecahan masalah matematis siswa dan dapat digunakan dalam pembelajaran (Nursyahidah, Saputro, Albab, \& Aisyah, 2020). Pemilihan media pembelajaran yang tepat dapat membantu siswa belajar secara efisien serta meningkatkan kemampuan pemecahan masalah matematis siswa (Sopian \& Afriansyah, 2017).

Menurut Khairani \& Febrinal (2016) media pembelajaran adalah faktor yang dapat membantu keberhasilan dalam proses pembelajaran di sekolah karena akan membantu guru dalam menyampaikan informasi kepada siswa ataupun sebaliknya (artinya media akan membantu guru dalam penyampaian materi). Melaui media, khususnya media yang jarang dijumpai, dapat menarik perhatian siswa dalam belajar. Suprihatiningrum (2013) mengemukakan bahwa media pembejalaran adalah alat dan bahan yang memuat dan membawa informasi atau bahan pelajaran agar tujuan pembelajaran bisa tercapai. Ada banyak jenis media pembelajaran yang dapat dikembangkan untuk meningkatkan 
kemampuan pemecahan masalah didik akan bisa mengajukan pertanyaan matematis diantaranya media (Herawati, ddk., 2010). Hodiyanto dan pembelajaran berbasis Macromedia Flash. Susiaty (2018) juga menyatakan bahwa

Macromedia Flash adalah platform multimedia dan perangkat lunak yang biasanya dimanfaatkan untuk game, animasi dan aplikasi pengayaan internet yang dapat dilihat, dimainkan, dan dijalankan di Adobe Flash Player (Kusumadewi dalam Masykur, ddk., 2017). Penggunaan macromedia flash sebagai media pembelajaran akan bermanfaat bagi pendidik sebagai alat bantu dalam membuat bahan ajar. Media ini dapat mendorong stimulus peserta didik agar konsep-konsep dapat dimanipulasikan serta hal-hal yang abstrak dapat dibuat dalam bentuk nyata.

Selain penggunaan media dalam pembelajaran tentunya untuk membantu tercapainya tujuan pembelajaran harus menggunakan metode, strategi, atau model pembelajaran yang sesuai dengan permasalahan yang dihadapi. Jadi untuk menyelesaikan permasalahan rendahnya kemampuan pemecahan masalah matematis pada siswa dapat digunakan strategi mengajar yang berorientasi pada masalah, salah satu diantaranya pembelajaran problem posing (Sofyan \& Madio, 2017).

Pembelajaran problem posing adalah pembelajaran yang memacu pada siswa untuk mengajukan soal (Afriansyah, 2017) berdasarkan informasi atau situasi yang diberikan. Informasi yang ada diolah dalam pikiran dan setelah dipahami maka peserta pembelajaram problem posing adalah pembelajaran yang mengharuskan peserta didik untuk mengajukan pertanyaanpertanyaan yang lebih sederhana yang mengacu pada penyelesaian soal tersebut, tetapi dalam pembuatan soal/pertanyaan tersebut tentu harus berdasarkan hasil diskusi dengan teman kelompoknya. Setelah pertanyaan dibuat, pertanyaan tersebut akan diserahkan kepada kelompok lain untuk didiskusikan penyelesaiannya. Dalam penyelesaian tersebut mahasiswa harus berdiskusi dengan teman kelompoknya untuk menemukan penyelesaian yang benar.

Hasil penelitian Hodiyanto, Budiono, \& Slamet (2016) menunjukkan bahwa pembelajaran problem posing dapat memperbaiki kemampuan komunikasi matematis siswa. Oleh sebab itu, pada penelitian ini, peneliti mencoba untuk menggunakan pembelajaran problem posing untuk mengatasi permasalah di SMP Negeri 5 Sukadana. Dengan demikian, penelitian ini merupakan penelitian lanjutan yang sebelumnya sudah peneliti lakukan tetapi perbedaannya terletak pada variabel terikatnya. Jika sebelumnya pembelajaran problem posing diterapkan untuk memperbaiki kemampuan komunikasi matematis, tetapi sekarang pembelajaran problem posing diterapkan untuk memperbaiki kemampuan pemecahan masalah matematis karena 
berdasarkan hasil penelitain Ariawan\& Nufus (2017) menunjukkan bahawa terdapat hubungan yang signifikan antara kemampuan pemecahan masalah matematis dengan kemampuan komunikasi matematis siswa. Xia et al. (2008: 154) juga menyatakan bahwa pembelajaran yang melibatkan aktivitas problem posing dapat menimbulkan ketertarikan siswa terhadap matematika, meningkatkan kemampuan mereka dalam mengajukan masalah dan meningkatkan kemampuan belajar matematika mereka dengan baik. Selain itu, pada penelitian ini penerapan pembelajaran problem posing akan dimodifikasi dengan media pembelajaran berbasis macromedia flash.

Dalam penelitian ini, peneliti ingin mencoba mengembangkan media pembelajaran berbasis macromedia flash bermuatan problem posing terhadap kemampuan pemecahan masalah artinya isi dari macromedia flash yang dikembangkan mengandung problem posing. Salah satu isi dari macromedia flash, siswa diminta untuk mengajukan pertanyakan dari informasi yang diberikan. Materi yang akan dikembangkan dalam penelitian ini adalah materi pola bilangan karena berdasarkan hasil UN tahun 2017/2018 diketahui bahwa presentase siswa menjawab benar hanya 41,94 pada materi bilangan. Hasil tersebut di bawah propinsi dengan presentase 45,99 dan nasional dengan presentasi 50,05.
II. Metode

Metode penelitian yang digunakan dalam penelitian ini adalah $R \& D$ (Research and Devolopment). Menurut Sugiyono (2015: 30) research and devolopment adalah penelitian yang digunakan untuk menghasilkan produk tertentu dan untuk menguji keefektifan produk tersebut. Produk yang dihasilkan berupa macromedia flash bermuatan problem posing terhadap kemampuan pemecahan masalah pada materi pola bilangan yang akan digunakan di Kelas VII SMP Negeri 5 Sukadana.

Rancangan penelitian ini menggunakan model pengembangan 4D, yaitu Define, Design, Develop, dan Desseminate oleh Thiagarajan (Sugiyono, 2015).

Pada penelitian ini model 4D dimodifikasi menjadi 3D disesuaikan dengan kebutuhan penelitian dengan tidak dilaksanakan sampai pada tahap disseminate (penyebaran) produk hasil penelitian dikarenakan waktu dan materi sangat terbatas. Berikut ini tahapan pelaksanaan penelitian menggunakan model 3D yang telah dimodifikasi, yaitu:

1. Pendefinisian (define)

Melakuakan analisis potensi dan masalah, menyusun informasi hasil observasi serta merumusakan tujuan pembelajaran. Dari hasil pra research, ditemukan rendahnya kemampuan pemecahan masalah matematis disebabkan model pembelajaran yang 
kurang bervariasi dan pemanfaatan media yang tidak optimal.

2. Perencanaan (design)

Membuat rancangan awal yang meliputi penyusunan instrumen (tes dan angket), pemilihan media dan desain awal dari media (desaian awal media pembelajaran macromedia flash bermuatan problem posing)

3. Pengembangan (develop)

Melakukan validasi desain, revisi media, dan uji coba.
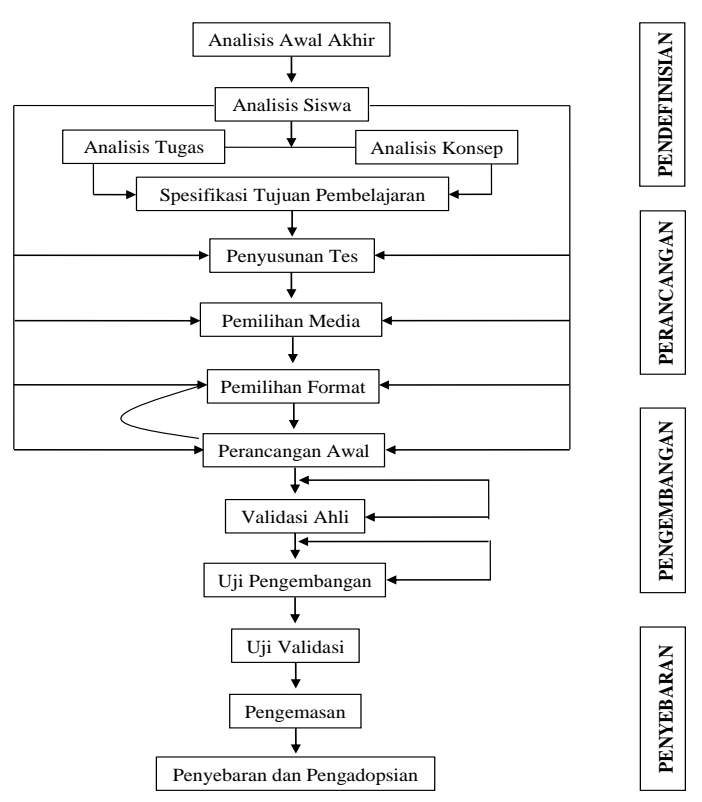

Gambar 1. Tahapan pelaksanaan penelitian

Subjek penelitian ini adalah siswa kelas VIII SMP Negeri 5 Sukadana, ahli dan guru. Penelitian ini akan dilaksanakan di SMP Negeri 5 Sukadana, Jalan Sukadana Desa Sejahtera Kecamatan Sukadana Kabupaten Kayong Utara. Adapun teknik pengumpulan data yang digunakan dalam penelitian ini adalah teknik pengukuran dan komunukasi tidak lansung, sedangkan alat pengumpul data yang digunakan dalam penelitian ini adalah tes kemampuan pemecahan masalah yang berupa essai dan angket yang berupa lembar validasi ahli materi, ahli media, angket respon guru dan angket respon siswa terhadap media pembelajaran.

Teknik analis data yang digunakan berupa statisik diskriptif. Adapun kriteria kevalidan, kepraktisan, dan keefektifan yang diadaptasi dari Bintiningtiyas (2016) dapat dilihat pada tabel di bawah ini.

Tabel 1.

Kriteria Persentase Kevalidan Produk

\begin{tabular}{|cc|}
\hline Persentase $(\%)$ & Kriteria Kepraktisan \\
\hline $80 \%<$ Skor $\leq 100 \%$ & Sangat Valid \\
\hline $60 \%<$ Skor $\leq 80 \%$ & Valid \\
\hline $40 \%<$ Skor $\leq 60 \%$ & Cukup Valid \\
\hline $20 \%<$ Skor $\leq 40 \%$ & Kurang Valid \\
\hline $0 \%<$ Skor $\leq 20 \%$ & Tidak Valid \\
\hline
\end{tabular}

Kriteria Persentase Kepraktisan Produk

\begin{tabular}{|c|c|}
\hline Persentase (\%) & Kriteria Kepraktisan \\
\hline $80 \%<$ Skor $\leq 100 \%$ & Sangat Praktis \\
\hline $60 \%<$ Skor $\leq 80 \%$ & Praktis \\
\hline $40 \%<$ Skor $\leq 60 \%$ & Cukup Praktis \\
\hline $20 \%<$ Skor $\leq 40 \%$ & Kurang Praktis \\
\hline $0 \%<$ Skor $\leq 20 \%$ & Tidak Praktis \\
\hline \multicolumn{2}{|c|}{ Tabel 3.} \\
\hline \multicolumn{2}{|c|}{ Kriteria Persentase Keefektifan Produk } \\
\hline Persentase (\%) & Kriteria Kepraktisan \\
\hline $80 \%<$ Skor $\leq 100 \%$ & Sangat Efektif \\
\hline $60 \%<$ Skor $\leq 80 \%$ & Efektif \\
\hline $40 \%<$ Skor $\leq 60 \%$ & Cukup Efektif \\
\hline $20 \%<$ Skor $\leq 40 \%$ & Kurang Efektif \\
\hline $0 \%<$ Skor $\leq 20 \%$ & Tidak Efektif \\
\hline
\end{tabular}

\section{Hasil dan PeMbahasan}

\section{A. Hasil Penelitian}

Setelah rancangan dan desain awal sudah dibuat maka dilanjutkan pada tahap pengembangan. Tahap pengembangan ini 
adalah validasi ahli dan uji coba pengembangan.

\section{Validasi Ahli}

Pada penelitian ini, validasi media ditelaah oleh 3 orang validator yang memahami dalam pembuatan macromedia flash bermuatan problem posing yaitu dua orang dosen program studi pendidikan matematika dan satu orang dosen program studi pendidikan teknologi informasi dan komputer. Saransaran dari validator dijadikan masukkan untuk merevisi media pembelajaran macromedia flash bermuatan problem posing sehingga media valid dan siap untuk di ujicobakan ke siswa kelas VIII SMP Negeri 5 Sukadana sebagai subjek penelitian. Di bawah ini akan dipaparkan hasil validasi ahli.

\section{a. Validasi oleh ahli materi}

Ahli materi memberikan penilaian dari aspek isi, penyajian, bahasa, dan penilaian pada media pembelajaran berbasis macromedia flash bermuatan problem posing. Adapaun rata-rata penilaian dari tiga ahli materi terhadap media dapat dilihat pada tabel 4 berikut:

Tabel 4.

Hasil Validasi Macromedia Flash Oleh Ahli Materi

\begin{tabular}{|llll|}
\hline No & Ahli Materi & Penilaian (\%) & Kriteria \\
\hline 1 & Validator 1 & $89,38 \%$ & Sangat Valid \\
\hline 2 & Validator 2 & $93,07 \%$ & Sangat Valid \\
\hline 3 & Validator 3 & $83,84 \%$ & Sangat Valid \\
\hline Rata-rata & $88,71 \%$ & Sangat Valid \\
\hline
\end{tabular}

Dari tabel 4 diperoleh bahwa hasil rata-rata persentase validasi dari tiga ahli materi sebesar 88,71\% dengan kriteria sangat valid sehingga media pembelajaran macromedia flash bermuatan problem posing layak digunakan. Terdapat beberapa masukan yang diberikan ahli untuk revisi. Setelah dilakukan revisi barulah media pembelajaran ini dapat digunakan dalam penelitian.

\section{b. Validasi oleh ahli media}

Ahli media memberikan penilaian terkait tiga indikator, yaitu ukuran macromedia flash, desain sampul macromedia flash, dan desain isi macromedia flash. Adapun rata-rata penilaian dari ahli media terhadap media pembelajaran macromedia flash bermuatan problem posing dapat dilihat pada tabel 5.

Tabel 5.

Hasil Validasi Macromedia Flash Oleh Ahli Media

\begin{tabular}{cccc|}
\hline No & Ahli Media & Penilaian (\%) & Kriteria \\
\hline 1 & Validator 1 & $76,77 \%$ & Valid \\
\hline 2 & Validator 2 & $88,38 \%$ & Sangat Valid \\
\hline 3 & Validator 3 & $83,22 \%$ & Sangat Valid \\
\hline & Rata-rata & $82,79 \%$ & Sangat Valid \\
\hline
\end{tabular}

Dari tabel 5 diperoleh rata-rata persentase hasil validasi dari tiga ahli media sebesar 82,79 \% dengan kriteria sangat valid sehingga layak digunakan. Terdapat beberapa masukan yang diberikan ahli untuk revisi. Setelah dilakukan revisi barulah media pembelajaran macromedia flash bermuatan problem posing ini dapat digunakan dalam penelitian.

\section{c. Hasil validasi ahli}

Berdasarkan hasil perhitungan validasi ahli materi dan ahli media maka diperoleh tingkat kevalidan media pembelajaran macromedia flash bermuatan problem 
posing. Hal ini dilakukan untuk menjawab tujuan penelitian pertama. Hasilnya ditunjukkan oleh tabel 6 sebagai berikut:

Tabel 6.

Hasil Validasi Ahli

\begin{tabular}{cccc}
\hline No & Ahli & Penilaian (\%) & Kriteria \\
\hline 1 & Ahli Materi & $88,71 \%$ & Sangat Valid \\
\hline 2 & Ahli Media & $82,79 \%$ & Sangat Valid \\
\hline & Rata-rata & $85,75 \%$ & Sangat Valid
\end{tabular}

Tabel 6. menampilkan tingkat validitas media pembelajaran macromedia flash bermuatan problem posing terhadap kemampuan pemecahan masalah matematis di kelas VIII SMP Negeri 5 Sukadana mempunyai kriteria sangat valid dengan persentase sebesar 85,75\%.

\section{Uji Coba Produk}

Setelah media pembelajaran macromedia flash bermuatan problem posing divalidasi dan di revisi, maka tahap selanjutnya yiatu melakukan uji coba produk pada sekolah tertentu. Sekolah yang menjadi tempat uji coba dalam penelitian ini adalah SMP Negeri 5 Sukadana untuk mengetahui kepraktisan dan keefektifan produk.

\section{a. Kepraktisan}

Tabel 7.

Kepraktisan Angket Respon Guru Dan Siswa

\begin{tabular}{|c|c|c|c|}
\hline No & Aspek & Penilaian (\%) & Kriteria \\
\hline 1 & Respon Guru & $94,11 \%$ & Sangat Valid \\
\hline 2 & Respon Siswa & $81,71 \%$ & Sangat Valid \\
\hline & Rata-rata & $87,91 \%$ & Sangat Valid \\
\hline
\end{tabular}

kepraktisan diisi oleh satu guru SMP Negeri 5 Sukadana yang melakukan uji coba produk dan siswa kelas VIII B sebanyak 20 siswa mengenai respon mereka terhadap media pembelajaran macromedia flash bermuatan problem posing yang telah digunakan selama proses pembelajaran. Selain itu, saran dan komentar respon terhadap media pembelajaran akan dipertimbangkan dalam revisi media pembelajaran.

Hasil perhitungan persentase indeks guru dan siswa diperoleh nilai persentase kepraktisan 87,91 \% dan termasuk pada kategori sangat praktis.

\section{b. Keefektifan}

Keefektifan pada penelitian ini dapat dilihat dari hasil posttest. Setelah dilakukan pembelajaran menggunakan media pembelajaran macromedia flash bermuatan problem posing, siswa diberikan posttest. Soal posttest berjumlah 5 soal.

Berdasarkan hasil posttest diperoleh 16 siswa tuntas, mencapai KKM sedangkan 4 orang siswa lainya tidak tuntas. Nilai ratarata 20 siswa kelas VIII sebesar 78,85. Dengan demikian, tingkat keefektifan media pembelajaran macromedia flash bermuatan problem posing terhadap kemampuan pemecahan masalah matematis dalam materi pola bilangan kelas VIII SMP Negeri 5 Sukadana dapat dikategorikan efektif karena ketuntasan klasikal memperoleh persentase sebesar $80 \%$.

\section{Produk Akhir}

Setelah dilakukan uji coba lapangan, hasil dari perbaikan berdasarkan masukan validator, guru, dan siswa terhadap media pembelajaran tersebut kemudian media 
pembelajaran siap untuk dikemas sebagai produk akhir.

\section{B. Pembahasan}

Pengembangan macromedia flash bermuatan problem posing terhadap kemampuan pemecahan masalah dalam materi pola bilangan pada siswa kelas VIII SMP NEGERI 5 sukadana menggunakan model pengembangan 4-D yang direkomendasikan Thiagarajan (Hamdani, 2010: 27) yang terdiri atas define, design, develop, dan disseminate. Tahap define bertujuan untuk mendefinisikan kebutuhan yang ada di lapangan sehingga peneliti mengetahui masalah yang terjadi di lapangan dan berusaha mencari serta memberikan solusinya. Pada tahap ini peneliti memperoleh informasi bahwa model pembelajaran yang kurang bervariasi dan pemanfaatan media yang tidak optimal adalah faktor yang paling utama dari rendahnya kemampaun pemecahan masalah matematis siswa. Tahap design bertujuan untuk membuat rancangan awal dari produk yang akan dikembangkan sesuai dengan kebutuhan di lapangan. Tahap develop bertujuan untuk mengembangkan produk yang telah direvisi berdasarkan masukkan dari para ahli dan uji coba produk. Tetapi dalam penelitian ini hanya sampai tahap pengembangan (develop) saja karena subjek penelitian hanya meliputi satu sekolah dan satu kelas mengingat hanya 1 kompetensi dasar yang dikembangkan sehingga tidak memungkinkan untuk dilakukan penyebaran.
Menurut pendapat Nieevan (Kurniawan, 2016) bahwa dalam penelitian pengembangan peneliti juga harus memperhatikan kualitas produk yang dihasilkan melalui pengujian tingkat validity (kevalidan), practically (kepraktisan), dan effectiveness (keefektifan). Dengan mengetahui kualitas produk yang dihasilkan, maka produk yang dihasilkan dapat digunkan oleh lingkungan yang lebih luas sesuai dengan tujuan pembuatannya. Dalam penelitian ini produk yang dihasilkan adalah media pembelejaran yang menggunakan software macromedia flash dalam materi pola bilangan.

Kevalidan macromedia flash diketahui melalui tahap validasi oleh ahli materi sekaligus ahli media yang menggunakan skala likert dan menggunakan rentang "81-100\% menunjukkan kriteria sangat valid. Analisa validasi macromedia flash oleh ahli materi diperoleh rata-rata persentase sebesar 82,79\% dengan kriteria sangat valid sehingga macromedia flash layak untuk digunakan.

Lembar validasi ahli media macromedia flash diperoleh rata-rata persentase sebesar $88,71 \%$ dengan kriteria sangat valid sehingga macromedia flash layak untuk digunakan. Adapaun hasil perhitungan ahli media dan ahli materi diperoleh rata-rata persentase sebesar $85,75 \%$ dengan kriteria sangat valid, sehingga macromedia flash yang dikembangkan dapat digunakan dengan sangat baik pada proses pembelajaran. 
Setelah selesai melakukan validasi, tahap selanjutnya ialah uji coba produk. Uji coba produk ini bertujuan untuk mengetahui kepraktisan terhadap macromedia flash yang dikembangkan dan untuk mengetahui keefektifan setelah menggunakan macromedia flash yang dikembangkan. Untuk mengetahui kepraktisan didapat rata-rata respon dari siswa untuk kepraktisan macromedia flash sebesar 81,71 \% dengan kriteria sangat praktis dengan melibatkan 20 siswa kelas VIII SMP Negeri 5 Sukadana. Sedangkan dari angket respon guru di peroleh persentase sebesar 94,11 \% dengan kriteria sangat praktis. Dari angket respon siswa dan guru didapatkan rata-rata nilai keparktisan sebesar 87,91 \% dengan kriteria sangat parktis.

Untuk mengetahui keefektifan macromedia flash dilakukan dengan cara memberikan posttest yang berisi 5 soal uraian. Posttest tersebut diberikan kepada subjek yang sama yaitu siswa kelas VIII SMP Negeri 5 Sukadana yang berjumlah 20 orang. Dari hasil penelitian menunjukkan bahwa hasil posttest tersebut menyatakan bahwa 16 siswa yang tuntas dan 4 orang siswa yang tidak tuntas karena nilai yang diperoleh berada dibawah KKM sehingga media scrapbook dapat dikatakan efektif kerana ketuntasan klasikal memperoleh persenatse sebesar $80 \%$. Hasil penelitian ini juga sejalan dengan penelitian yang dilakukan oleh Khairani dan Febrinal (2016) hasil macromedia flash yang memperoleh hasil penelitian untuk tingkat kevalidan dengan rata-rata skor penilaian validator 74,64 \% denga kriteria sangat valid, dari hasil kepraktisan dengan ratarata $87,56 \%$ yang termasuk dalam kategori praktis, dan tingkat keefektifan dengan rata-rata $78 \%$ yang tergolong sangat efektif untuk digunakan.

Hasil penelitian ini juga sesuai dengan hasil penelitian sebelumnya bahwa pembelajaran dengan menggunakan media macromedia flash dalam pembelajaran matematika dapat meningkatkan kemampuan pemecahan masalah matematis peserta didik (Serin, 2011; Serin, Serin \& Saygılı, 2009; dan Adiguzel \& Akpinar, 2004).

Pada penelitian ini macromedia flash yang dikembangkan bermuatan problem posing pada materi pola bilangan. Macromedia flash tersebut dibuat berdasarkan langkah-langkah problem posing. Macromedia flash yang dikolaborasikan dengan model pembelajaran problem posing selain media pembelajaran interaktif juga terdapat informasi yang dapat membuat siswa mengajukan soal sendiri dan dapat menyampaikan inoformasi dengan jelas, berisi tulisan, gambar, dan materi yang singkat jelas sehingga dapat menarik perhatian siswa. Dengan demikian, pembelajaran dengan macromedia flash yang bersifat interaktif akan membantu siswa dalam membuat dan mengajukan soal yang akan diberikan kepada kelompok lain. Selain itu, siswa juga diminta untuk memecahkan soal yang diberikan oleh 
kelompok lain. Oleh sebab itu, pembelajaran dengan macromedia flash bermuatan problem posing akan membantu siswa dalam mengembangkan kemampuan pemecahan masalah matematisnya karena selain mereka dituntut untuk mengajukan soal dari informasi yang diberikan, mereka juga dituntut untuk menyelesaikan soal yang diajukan oleh kelompok yang lain. Hasil penelitian ini didukung dengan hasil penelitian Rosli, Capraro \& Capraro (2014) bahwa pembelajaran problem posing dapat bermanfaat dan berpengaruh terhadap kemampuan pemecahan masalah matematis peserta didik.

Langkah-langkah problem posing yang termuat dalam macromedia flash sebagai berikut: (1) Penyampaian tujuan pembelajaran. Pada tahap ini siswa diharuskan untuk mengetahui tujuan pembelajaran dan materi yang akan dipelajari. (2) Pemberian materi, contoh soal, dan soal latihap. Pada tahap ini sebagai latihan siswa sebagai pengetahuan awal dalam memahami materi. (3) Pemberian informasi. Pada tahap ini siswa diminta untuk membuat dan mengajukan soal dari informasi yang telah diberikan. (4) Penyelesaian soal. Pada tahap ini siswa dilatih untuk menyelesaikan soal yang telah dibuatnya. (5) Pendalaman materi. Pada tahap ini dilakukan untuk mengetahui seberapa pahamnya siswa dapat mempelajari materi.

\section{Penutup}

Berdasarkan hasil penelitian dan pembahasan maka secara umum dapat disimpulkan bahwa pengembangan macromedia flash bermuatan problem posing terhadap kemampuan pemecahan masalah dalam materi pola bilangan pada siswa kelas VIII SMP NEGERI 5 sukadana, tergolong baik digunakan.

\section{UCAPAN TERIMA KASIH}

Terima kasih kami sampaikan kepada IKIP PGRI Pontianak atas dana Hibah Penelitian Kompetiti Tahun Anggaran 2019 yang telah diberikan.

\section{DAFTAR PUSTAKA}

Adiguzel, T., \& Akpinar, Y. (2004). Improving School Children's Mathematical Word Problem Solving Skills through Computer-Based Multiple Representations. Association for Educational Communications and Technology.

Afriansyah, E. A. (2017). Problem Posing sebagai Kemampuan Matematis. Mosharafa: Jurnal Pendidikan Matematika, 6(1), 163-180.

Ariawan, R., \& Nufus, H. (2017). Hubungan Kemampuan Pemecahan Masalah Matematis dengan Kemampuan Komunikasi Matematis Siswa. Theorems (The Original Research of Mathematics), 1(2).

Bintiningtiyas, N. (2016). Pengembangan Permainan Varmintz Chemistry Sebagai Media Pembelajaran pada 
Materi Sistem Periodik Unsur (Development of Varmintz Chemistry as Learning Media on Periodic System of Element). Unesa Journal of Chemical Education, 5(2).

Hanifah, H. R. F. N., \& Nuraeni, R. (2020). Perbedaan Peningkatan Kemampuan Pemecahan Masalah Matematis Siswa antara Think Pair Share dan Think Talk Write. Mosharafa: Jurnal Pendidikan Matematika, 9(1), 155-166.

Hendriana, R., Rohaeti, E. E., \& Sumarmo (2017). Hard Skills and Soft Skills of Student Mathematics. Bandung: PT Refika Aditama.

Herawati, O. D. P., Siroj, R. A., \& Basir, M. D. (2010). Pengaruh pembelajaran problem posing terhadap kemampuan pemahaman konsep matematika siswa kelas xi ipa sma negeri 6 palembang. Jurnal Pendidikan Matematika, 4(1), 70-80.

Hodiyanto, H. \& Susiaty, U. D. (2018) Peningkatan Kemampuan Pembuktian Matematis Melalui Model Pembelajaran Problem Posing. Jurnal Matematika dan Pembelajaran, 6(1). Hodiyanto, H., Budiyono, B., \& Slamet, I. (2016). Eksperimentasi model pembelajaran problem posing dan problem solving dengan pendekatan pmr terhadap prestasi belajar dan kemampuan komunikasi matematis ditinjau dari kreativitas siswa kelas VII SMP Negeri di Kabupaten Sukoharjo. Jurnal Pembelajaran Matematika, 4(2).
Khairani, M., \& Febrinal, D. (2016). Pengembangan media pembelajaran dalam bentuk macromedia flash materi tabung untuk SMP kelas IX. Jurnal Ipteks Terapan, 10(2), 95-102.

Latifah, S. S., \& Luritawaty, I. P. (2020). Think Pair Share sebagai Model Pembelajaran Kooperatif untuk Peningkatan Kemampuan Pemecahan Masalah Matematis. Mosharafa: Jurnal Pendidikan Matematika, 9(1), 35-46.

Masykur, R., Nofrizal, \& Syazali, M. (2017). Pengembangan Media Pembelajaran Matematika dengan Macromedia Flash. Jurnal Pendidikan Matematika, Vol 8 (2), 177-186.

National Council of Teachers of Mathematics (Ed.). (2000). Principles and standards for school mathematics (Vol. 1). National Council of Teachers.

Nursyahidah, F., Saputro, B. A., Albab, I. U., \& Aisyah, F. (2020). Pengembangan Learning Trajectory Based Instruction Materi Kerucut Menggunakan Konteks Megono Gunungan. Mosharafa: Jurnal Pendidikan Matematika, 9(1), 47-58.

Rinaldi, E., \& Afriansyah, E. A. (2019). Perbandingan Kemampuan Pemecahan Masalah Matematis Siswa antara Problem Centered Learning dan Problem Based Learning. NUMERICAL: Jurnal Matematika dan Pendidikan Matematika, 9-18. 
Rosli, R., Capraro, M. M., \& Capraro, R. M. (2014). The Effect of Problem Posing on Student Mathematical Learning: A Meta-Analysis. International Education Studies, 7(13), 227-240.

Serin, O. (2011). The Effects of the Computer-Based Instruction on the Achievement and Problem Solving Skills of the Science and Technology Students. Turkish Online Journal of Educational Technology-TOJET, 10(1), 183-201.

Serin, O., Serin, N. B., \& Saygılı, G. (2009). The effect of educational technologies and material supported science and technology teaching on the problem solving skills of 5th grade primary school student. Procedia-Social and Behavioral Sciences, 1(1), 665-670.

Sofyan, D., \& Madio, S. S. (2017). Meningkatkan Kemampuan

Pemecahan Masalah dan Komunikasi Matematik melalui Pendekatan Problem Posing dalam Pembelajaran Matematika di SMA. Mosharafa: Jurnal Pendidikan Matematika, 6(1), 93-104.

Sopian, Y., \& Afriansyah, E. A. (2017). Kemampuan Proses Pemecahan Masalah Matematis Siswa Melalui Model Pembelajaran Creative Problem Solving dan Rerource Based Learning. Jurnal Elemen, 3(1), 97-107. Sugiyono. (2015). Metode Penelitian \& Pengembangan (Research and Development). Bandung: Alfabeta.
Suprihatiningrum, J. (2013). Strategi Pembelajaran Teori dan Aplikasi. Yogyakarta: ARRuzz Media.

Xia, X., Lu, C., \& Wang, B. (2008). Research of Mathematics Intruction Experiment Based Problem Posing. Journal of Mathematics Education, 1(1), 153-16.

\section{RIWAYAT HIDUP PENULIS}

\section{Hodiyanto, M.Pd.}

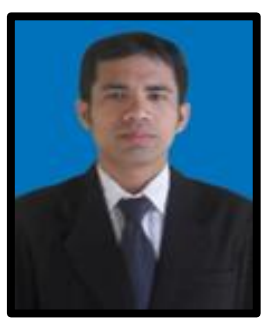

Lahir di Sambas, 05 Oktober 1985. Staf pengajar di IKIP PGRI Pontianak. Studi S1 Pendidikan Matematika STKIP PGRI Pontianak, lulus tahun 2013; S2 Pendidikan Matematika Universitas Sebelas Maret Surakarta (UNS), lulus tahun 2016.

\section{Yudi Darma, M.Pd.}

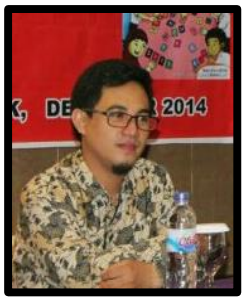

Lahir di Pontianak, 19 Juni 1987. Staf pengajar di IKIP PGRI Pontianak. Studi S1 Pendidikan Matematika STKIP PGRI Pontianak, lulus tahun 2009; S2 Pendidikan Matematika Universitas Sebelas Maret Surakarta (UNS), lulus tahun 2012.

\section{Syarif Restian Sarisma Putra}

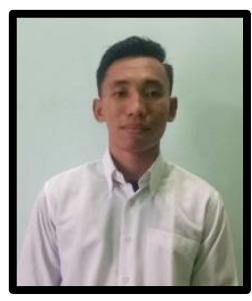

Lahir di Siduk, 18 januari 1995. Program Studi Pendidikan Matematika IKIP PGRI Pontianak lulus tahun 2020. 